УДК 614.253.5:614.212

DOI 10.11603/2411-1597.2021.2.12280

\title{
ПРОФЕСІЙНА САМОРЕАЛІЗАЦІЯ МЕДИЧНОЇ СЕСТРИ АМБУЛАТОРІЇ СІМЕЙНОЇ МЕДИЦИНИ
}

\author{
М. П. Карась ${ }^{1}$ Ю. Я. Коцаба ${ }^{2}$ \\ ${ }^{1}$ Комунальне некомерційне підприємство «Тернопільський обласний клінічний \\ перинатальний центр "Мати і дитина" Тернопільської обласної ради \\ ${ }^{2}$ Тернопільський національний медичний університет \\ імені І. Я. Горбачевського МОЗ Украӥни
}

У статті наведено результати дослідження, в ході якого вивчали рівень професійної самореалізації серед медичних сестер амбулаторії сімейної медицини.

\section{PROFESSIONAL SELF-REALIZATION OF THE NURSE OF THE FAMILY MEDICINE CLINIC}

\author{
M. P. Karas' ${ }^{1}$ Yu. Ya. Kotsaba ${ }^{2}$ \\ ${ }^{1}$ Communal non-profit enterprise «Ternopil Regional Clinical Perinatal Center \\ "Mother and Child" of Ternopil Regional Council \\ ${ }^{2}$ I. Horbachevsky Ternopil National Medical University
}

The article presents the results of a study in which the level of professional self-realization among nurses of the family medicine outpatient clinic was studied.

Вступ. Сімейна медицина є однією з найефективніших стратегій підвищення результативності системи охорони здоров'я в цілому, а також справедливого розподілу і раціонального використання бюджетних асигнувань в галузі. Вона спрямована на вирішення проблем збереження і зміцнення здоров'я всього населення. Такий підхід підтримала Всесвітня організація охорони здоров'я (ВООЗ), яка в головному стратегічному документі «Здоров'я для всіх у XXI столітті» визначила розвиток первинної медико-санітарної допомоги на принципах сімейної медицини одним із головних завдань для європейських країн. Системи первинної медико-санітарної допомоги в країнах Європи досить різні, що відповідає історичним умовам їх розвитку, але в основу більшості з них покладені принципи загальної практики - сімейної медицини [3].

Якісна медична допомога в сімейній медицині це досягнення оптимальних результатів фізичного, психічного та поведінкового здоров'я за допомогою доступної, безпечної, економічно ефективної, спра-

(c) М. П. Карась, Ю. Я. Коцаба, 2021 ведливої допомоги, яка ґрунтується на найкращих доказах, відповідає потребам та уподобанням пацієнтів та населення, а також поважає сім'ї пацієнтів, особисті цінності та переконання (ВОО3, 2000).

Первинна медико-санітарна допомога задовольняє більшість потреб здоров'я людини протягом усього життя. Поняття «здоров'я» включає фізичне, психічне та соціальне благополуччя, орієнтоване на людей, а не на захворювання. Первинна медикосанітарна допомога - це підхід цілого суспільства, що включає зміцнення здоров'я, профілактику захворювань, лікування, реабілітацію та паліативну допомогу [4].

Роль медичної сестри у системі надання первинної медико-санітарної допомоги є надзвичайно важливою. Вона - рівноправний учасник лікувальнопрофілактичного процесу, насамперед у діяльності сімейної амбулаторії. Розуміючи, що їхні пацієнти унікальні особистості, медсестра допомагає лікарю у попередженні захворювань, своєчасному виявленні проблем у стані їхнього здоров'я, координації надання медичної допомоги. 
Спільна, злагоджена робота тандему: лікар і медсестра загальної практики - запорука профілактики та зниження захворюваності. Тому команда медпрацівників загальної практики повинна налагодити комплаєнс зі своїми пацієнтами.

Важливим фактором в ефективному виконанні своїх професійних обов'язків $є$ задоволеність працею.

Визначено, що задоволеність працею як показник ставлення до праці дає можливість розглядати ії як одну з головних потреб сучасної людини, під впливом якої формуються і ціннісні орієнтації, і мотиви. У свою чергу це забезпечує високі індивідуальні та колективні результати трудової діяльності.

Задоволеність працею можна розглядати на двох рівнях:

1 рівень - афективне задоволення працею;

2 рівень - когнітивне задоволення працею.

Афективне задоволення від роботи - це емоційне відчуття з приводу роботи в цілому. А когнітивне розглядається як пізнавальна задоволеність працею - наскільки задоволені співробітники, їх відчуття щодо деяких аспектів праці, таких, як: заробітна плата, інші матеріальні та нематеріальні вигоди.

Задоволеність працею формується під впливом низки факторів, серед яких найбільшу роль відіграють такі, як:

1) оплата праці;

2) власне праця;

3) особистісний інтерес до роботи як такої;

4) можливості просування по службі;

5) стиль керівництва, лідерство;
6) колеги, товариські відносини в колективі;

7) умови роботи.

Вчені доводять, що більшість працівників не відчуває повної задоволеності від своєї роботи, так само як і не відчуває сильної незадоволеності [1, 2].

Тому вивчення рівня задоволеності працею серед медичних сестер амбулаторії сімейної медицини $€$ актуальним.

Основна частина. Опитування проводили за допомогою опитувальника професійного самоздійснення.

Перша частина опитувальника призначена для з'ясування загального рівня професійної реалізації фахівця, а також для визначення ступеня вираження окремих його складових.

У другій частині опитувальника досліджуваному пропонують у довільній формі описати, яким чином професійна діяльність створює можливості для професійної реалізації.

Опитувальник містить 30 запитань, на кожне 3 яких пропонують 5 варіантів відповіді: від 0 до 4 балів (більша кількість балів відповідає вищому рівню професійної самореалізації).

У ході виконання дослідження проведено опитування 19 медичних сестер амбулаторій сімейної медицини м. Тернополя та Тернопільської області.

Середній вік опитуваних становив $(48,05 \pm 1,99)$ року, середня тривалість роботи за спеціальністю $(20,16 \pm 1,84)$ року, всі опитувані - жінки.

У таблиці наведено результати аналізу опитування досліджуваної групи.

Таблиця. Показники стандартизації опитувальника професійного самоздійснення

\begin{tabular}{|c|l|c|c|}
\hline № 3/п & \multicolumn{1}{|c|}{ Показник } & M & $\sigma$ \\
\hline I & Загальний рівень професійного самоздійснення фахівця: & 76,42 & 1,02 \\
\hline 1 & Рівень внутрішньопрофесійного самоздійснення: & 37,16 & 0,85 \\
\hline a) & Потреба у професійному вдосконаленні & 8,05 & 0,49 \\
\hline b) & Наявність проекту власного професійного розвитку & 5,84 & 0,60 \\
\hline с) & Переважаюче задоволення власними професійними досягненнями & 7,84 & 0,45 \\
\hline d) & Постійна постановка нових професійних цілей & 8,79 & 0,58 \\
\hline е) & Формування власного «життєво-професійного простору» & 6,63 & 0,60 \\
\hline 2 & Рівень зовнішньопрофесійного самоздійснення: & 39,26 & 1,09 \\
\hline a) & Досягнення поставлених професійних цілей & 8,63 & 0,36 \\
\hline b) & Визнання досягнень фахівця професійним співтовариством & 7,95 & 0,61 \\
\hline с) & Використання професійного досвіду та здобутків іншими фахівцями & 8,26 & 0,51 \\
\hline d) & Розкриття особистісного потенціалу і здібностей у професії & 8,63 & 0,52 \\
\hline е) & Вияв високого рівня творчості у професійній діяльності & 5,79 & 0,39 \\
\hline
\end{tabular}


За результатами аналізу було встановлено, що рівень внутрішньо- та зовнішньопрофесійної самореалізації знаходився на одному рівні.

Серед факторів внутрішньопрофесійної самореалізації найбільш вираженим був рівень «Потреби у професійному вдосконаленні» та «Постійної постановки нових професійних цілей». А поміж зовнішньопрофесійних факторів самоздійснення - «Використання професійного досвіду та здобутків іншими

\section{СПИСОК ЛІТЕРАТУРИ}

1. Кокун О. М. Опитувальник професійного самоздійснення / О. М. Кокун // Практична психологія та соціальна робота. - 2014. - № 7. - С. 35-39.

2. Кокун О. М. Життєве та професійне самоздійснення як предмет дослідження сучасної психології / О. М. Кокун // Практична психологія та соціальна робота. - 2013. № 9. - С. 1-5. фахівцями» і «Розкриття особистісного потенціалу і здібностей у професії».

А показники «Наявність проекту власного професійного розвитку» та «Вияв високого рівня творчості у професійній діяльності» були на найнижчому рівні.

Висновки. За результатами проведеного опитування медичних сестер амбулаторії сімейної медицини, можна вважати, що їх професійна самореалізація знаходиться на рівні вище середнього.

3. Антропова Т. О. Медсестринство в сімейній медицині : підручник для студентів / Т. О. Антропова. - К. : Медицина, 2008. - 486 с.

4. Phillips W. R. The domain of family practice: scope, role, and function / W. R. Phillips, D. G. Haynes // Fam. Med. 2001. - Apr. - Vol. 33 (4). - P. 273-277.

Отримано 19.04.21 